\title{
Index to Volume 10
}

Citation refers to Issue Number and Page Number

Number Page

Agnes, storm, tropical, geologic effects of, on upper Chesapeake Bay: ZABAWA

Air photograph and computer simulated wave refraction patterns in the nearshore area, Richibucto, Canada and Jervis Bay, Australia, a comparison of: BRYANT

AKPATI, B.N., Mineral composition and sediments in eastern Long Island Sound, New York

ALI, S.I., see O'BRIEN, N.R.

3107

Area, Kitty's Brook Chain Lakes, of westcentral Newfoundland, unusual till ridges in the: TUCKER

Area, nearshore, Richibucto Bay, Canada and Jervis Bay, Australia, a comparison of air photographs and computer simulated wave refraction patterns in the: BRYANT

Australia, a comparison of air photographs and computer simulated wave refraction patterns in the nearshore areas, Richibucto Bay, Canada and Jervis Bay: BRYANT

Bay, Chesapeake, upper, geologic effects of tropical storm Agnes on: ZABAWA 3

Bay, Great South, western, and south Oyster Bay, Long Island, New York: clay mineral composition of bottom sediments: $0: B R I E N$

Bay, Jervis, Australia, a comparison of air photographs and computer simulated wave refraction patterns in the nearshore areas, Richibucto Bay, Canada and: BRYANT

Bay, Richibucto, Canada, and Jervis Bay, Australia, a comparison of air photographs and computer simulated wave refraction patterns in the nearshore area: BRYANT

Bay, south Oyster, Long Island, New York, clay mineral composition of bottom sediments: western Great South Bay and: O'BRIEN

Benthic foraminifera, Pleistocene, late, of the southern Champlain sea: paleotemperatures and paleosalinity indicators: FILLON

Bottom sediments: western Great South Bay and south Oyster Bay, Long Island, New York: clay mineral compositon of: O'BRIEN

BRYANT, E.A., A comparison of air photograph and computer simulated wave refraction patterns in the nearshore areas, Richibucto, Canada and Jervis Bay, Australia

Canada, and Jervis Bay, Australia, a comparison of air photographs and computer simulated wave refraction patterns in the nearshore areas, Richibucto Bay: BRYANT
Chain Lakes, Kitty's Brook, area of westcentral Newfoundland, unusual till ridges in the: TUCKER

Champlain sea, late Pleistocene benthic foraminifera of the southern:" paleotemperature and paleosalinity indicators: FILLON

Number Page

Chemistry, water, of the st. Iawrence River: SUBRAMANIAN

Chesapeake Bay, upper, geologic effects of tropical storm Agnes on: ZABAWA 3

Clay mineral composition of bottom sediments western Great South Bay and south Oyster Bay, Iong Island, New York: O'BRIEN

Coast, Fundy, morphological maps of the: WELSTED

Comparison, a, of air photograph and computer simulated wave refraction patterns in the nearshore area, Richibucto, Canada and Jervis Bay, Australia: BRYANT

Composition, mineral, and sediments in eastern Long Island Sound, New York: AKPATI

Composition, mineral, clay, of bottom sediments: western Great South Bay and south Oyster Bay, Long Island, New York: O'BRIEN

Computer simulated wave refraction patterns in the nearshore area, Richibucto, Canada and Jervis Bay, Australia, a comparison of air photographs and: BRYANT

Deltaic and shallow marine Lower Silurian sediments of the Niagara Escarpment between Hamilton, Ontario and Rochester, New York, - A field guide: MARTINI 2 Deltas, raised, Pleistocene, a series of; Halls Beach, Newfoundland: TUCKER

Effects, geologic, of tropical storm Agnes on upper Chesapeake Bay: ZABAWA 3

Escarpment, Niagara, between Hamilton, Ontario, and Rochester, New York, deltaic and shallow marine Lower Silurian sediments of the, - A field guide: MARTINI

Field, guide, a, - Deltaic and shallow marine Lower Silurian sediments of the Niagara Escarpment between Hamilton, Ontario, and Rochester, New York: MARTINI 2

FILION, R.H., Late Pleistocene benthic foraminifera of the southern Champlain sea: paleotemperature and paleosalinity indicators of the southern Champlain sea: paleotemperature and paleosalinity indicators: FILLON

Fundy coast, morphological maps of the: WELSTED 
Fundy National Park, New Brunswick, geomorphology of the: GREINER

Geologic effects of tropical Storm Agnes on upper Chesapeake Bay: ZABAWA

Geomorphology of the Fundy National Park, New Brunswick: GREINER

Great South Bay, western, and south Oyster Bay, Long Island, New York: clay mineral composition of bottom sediments: O'BRIEN

GREINER, H., Geomorphology of the Fundy National Park

Guide, field, a, - Deltaic and shallow marine Lower Silurian sediments of the Niagara Escarpment between Hamilton, Ontario and Rochester, New York: MARTINI

he

Halls Beach, Newfoundland: A series of raised Pleistocene deltas: TUCKER

Hamilton, Ontario and Rochester, New York, deltaic and shallow marine Lower Silurian sediments of the Niagara Escarpment between, a field guide: MARTINI

Indicators, palesalinity, paleotemperature and late Pleistocene benthic foraminifera of the southex Champlain sea: FILLON

Jervis Bay, Australia, a comparison of air photographs and computer simulated wave refraction patterns in the nearshore areas, Richibucto Bay, Canada and: BRYANT

Kitty's Brook Chain Lakes area of westcentral Newfoundland, unusual till ridges in the: TUCKER

Late Pleistocene benthic foraminifera of the southern Champlain sea: paleotemperature and paleosalinity indicators: FILLON

Long Island, New York; clay mineral composition of bottom sediments: western Great South Bay and south Oyster Bay: O'BRIEN

Lower Silurian sediments, marine, shallow, deltaic and, of the Niagara Escarpment between Hamilton, Ontario, and Rochester, New York, - A field guide: MARTINI.

Maps, morphological, of the Fundy coast: WELSTED

Marine, shallow, Lower Silurian sediments, deltaic and, of the Niagara Escarpment between Hamilton, Ontario, and Rochester, New York, - A field guide: MART IN I

MARTINI, P., Deltaic and shallow marine Lower Silurian sediments of the Niagara Escarpment between Hamilton, Ontario, and Rochester, New York - A field guide.
Mineral, clay, composition of bottom sediments: western Great South Bay and south Oyster Bay, Long Island, New York: O'BRIEN

Mineral composition and sediments in eastern Long Island Sound, New York: AKPATI

Morphological maps of the Fundy coast: WELSTED

National Park, Fundy, New Brunswick, geomorphology of the: GREINER

Nearshore area, Richibucto Bay, Canada and Jervis Bay, Australia, a compaxison of air photographs and computer simulated wave refraction patterns in the: BRYANT

Newfoundland, Halls Beach; A series of raised Pleistocene deltas: TUCKER, 1

Newfoundland, Unusual till ridges in the Kitty's Brook Chain Lakes area of west-central: TUCKER

New Brunswick, geomorphology of the Fundy National Park: GREINER

New York, clay mineral composition of bottom sediments: western Great South Bay and south Oyster Bay, Long Island: O'BRIEN

New York, deltaic and shallow marine Lower Siluxian sediments of the Niagara Escarpment between Hamilton, Ontario, and Rochester, - A field guide: MARTINI

New York, mineral composition and sediments in eastern Long Island Sound: AKPATI I

Niagara Escarpment between Hamilton, Ontario, and Rochester, New York, deltaic and shallow marine Lower Silurian sediments of the; - A field guide: MARTINI

O'BRIEN, N.W. and ALI, S.I., Clay mineral composition of bottom sediments: western Great South Bay and south Oyster Bay, Long Island, New York. 3

Ontario, and Rochester, New York, deltaic and shallow marine Lower Silurian sediments of the Niagara Escarpment between Hamilton, - A field guide: MARTINI

Paleosalinity indicators, paleotemperature and late Pleistocene benthic foraminifera of the southern Champlain sea: FILLON

Paleotemperature and paleosalinity indicators: late Pleistocene benthic foraminifera of the southern Champlain sea: FILLON

Park, Fundy, National, New Brunswick, geomorphology of the: GREINER

Patterns, refraction, waves, computer simulated, in the nearshore area, Richibucto Bay, Canada and Jervis Bay, Australia, a comparison of air photographs and: BRYANT 
Photograph, air, and computer simulated wave refraction patterns in the nearshore area, Richibucto, Canada and Jervis Bay, Australia, a comparison of: BRYANT

Pleistocene, late, benthic foraminifera of the southern Champlain sea: paleotemperature and paleosalinity indicators: FILION

Raised Pleistocene deltas, a series of Halls Bay, Newfoundland: TUCKER

Refraction patterns, waves, computer simulated, in the nearshore area, Richibucto Bay, Canada and Jervis Bay, Australia, a comparison of air photograps and: BRYANT

Richibucto Bay, Canada, and Jervis Bay, Australia, a comparison of air photographs and computer simulated wave refraction patterns in the nearshore area: BRYANT

Ridges, till, unusual, in the Kitty's Brook Chain Lakes area of west-central Newfoundland: TUCKER

River, St. Lawrence, water chemistry of the: SUBRAMANIAN

Rochester, New York, deltaic and shallow marine Lower Silurian sediments of the Niagara Escarpment between Hamilton, Ontario and, - A field guide: MARTINI

SCHUBEL, J.R., see ZABAWA, C.F.

foraminifera of the southern: paleotempeature and paleosalinity indicators: FILLON

Sediments, bottom: western Great South Bay and south Oyster Bay, Long Island, New York: clay mineral composition of: O'BRIEN

Sediments in eastern Long Island Sound, New York; mineral composition and: AKPATI

Sediments, Silurian, Lower, marine, shallow, deltaic and of the Niagara Escarpment between Hamilton, Ontario, and Rochester, New York, A field guide: MARTINI Halls Bay, Newfoundland: TUCKER

Shallow marine Lower Silurian sediments, deltaic and, of the Niagara Escarpment between Hamilton, Ontario, and Rochester, New York, - A field guide: MARTINI

Silurian sediments, Lower, marine, shallow, deltaic and, of the Niagara Escarpment between Hamilton, Ontario, and Rochester, New York, - A field guide: MARTINI

Simulated wave refraction patterns, computex, in the nearshore area, Richibucto, Canada and Jervis Bay, Australia, a comparison of air photographs and: BRYANT
Sound, Long Island, New York, mineral composition and sediments in eastern: AKPATI

South Oyster Bay, Long Island, New York clay mineral composition of bottom sediments: western Great South Bay and: O'BRIEN

St. Lawrence River, water chemistry of the: SUBRAMANIAN 3

Storm, Agnes, tropical, geologic effects of, on Upper Chesapeake Bay: ZABAWA 3

SUBRAMANIAN, $v_{.}$, water chemistry of the st. Lawrence River

Till ridges, unusual, in the Kitty's Brook Chain Lakes area of westcentral Newfoundland: TUCKER

Tropical storm Agnes, geologic effects of, on upper Chesapeake Bay: ZABAWA

TUCKER, C.M०, A series of raised Pleistocene deltas; Halls Bay, Newfoundland

TUCKER, C.M., Unusual till ridges in the Kitty's Brook Chain Lakes area of west central Newfoundland

Unusual till ridges in the Kitty's Brook Chain Lakes area of westcentral Newfoundland: TUCKER

Upper Chesapeake Bay, geologic effects of tropical storm Agnes on: zABAWA

Water Chemistry of the St. Lawrence River: SUBRAMANIAN

Wave refraction patterns, computer simulated, in the nearshore area, Richibucto Bay, Canada and Jervis Bay, Australia, a comparison of air photographs and: BRYANT

WELSTED, J.Wo, Morphological maps of the Fundy coast.

246

Western Great South Bay and south Oyster Bay, Long Island, New York: clay mineral composition of bottom sediments: O'BRIEN

ZABAWA, CoF。, and SCHUBEL, JoRo, Geologic effects of tropical storm Agnes on Upper Chesapeake Bay 